Article

\title{
Project Implementation Management Modalities and Their Implications on Sustainability of Water Services in Rural Areas in Ethiopia: Are Community-Managed Projects More Effective?
}

\author{
Fekadu Megersa Senbeta ${ }^{1}$ and Yang Shu ${ }^{2, *(1)}$ \\ 1 School of Economics, Huazhong University of Science and Technology, Wuhan 430074, China; \\ fekadu@hust.edu.cn \\ 2 School of Economics and Trade, Hunan University, Changsha 410008, China \\ * Correspondence: shuy@hnu.edu.cn
}

Received: 21 January 2019; Accepted: 19 March 2019; Published: 20 March 2019

check for updates

\begin{abstract}
The study examines the impact of project implementation management approaches on the sustainability outcomes of rural water services in Ethiopia. A random selection of 102 water access points managed by the community, local government, and other external actors (charity and non-governmental organizations (NGOs)) were made to comparatively assess the sustainable outcomes of each. The analysis of the study is based on a unique set of data that constitutes interview results gathered from 612 beneficiary households, observation of 102 water access points, and another set of interviews held with 387 water supply, sanitation, and hygiene committee (WASHCO) members drawn from 102 water supply services. Additionally, document analysis was conducted on the records that were kept by all the 102 WASHCOs. One-way ANOVA and chi-square analysis was employed to assess and test the existence of significant differences among project implementation management approaches. The result showed the existence of a significant difference in most of the sustainability variables among project implementation management modalities under the study. As to the findings, the community-managed project approach generated a relatively higher and statistically significant sustainability outcome as compared to the others. Nevertheless, environmental sustainability indicators lack a statistically significant relationship. Overall, the key findings suggest that, in addition to demand-driven interventions, if the communities are empowered with the management and decision-making role of constructing their water points, the benefits of continuous delivery and sustainability of services can be maximized.
\end{abstract}

Keywords: sustainability; community; community-managed project; sustainability assessment indicators; rural water supply

\section{Introduction}

Developing countries are working towards the provision of safe and affordable drinking water services to their citizens. This is due to the fact that the global community is working towards the realization of sustainable development goals $[1,2]$ which is no exception for developing countries. The cost of inaction leads to negative social [3], economic [4], and environmental [5] impacts in the areas inhabited by populations that do not have access to clean water services. Reports revealed that lack of access to clean water and subsequent poor sanitation cost countries between $0.5 \%$ and $4.3 \%$ of their annual GDP [4], in addition to the toll that it takes on their time and energy traveling to and from water sources [6]. Lack of safe and improved drinking water supply causes diseases, such as diarrhea, cholera, dysentery, typhoid, and polio, resulting in the death of more than 0.36 million people 
each year [7]. These data show that working towards achieving SDGs of the water sector can greatly improve the lives and health of the population in the region.

Ninety-one percent of the world population had access to improved water supply services with some gap between urban and rural areas in the year 2015, though there existed a significant disparity among regions [6]. The sub-Saharan Africa region had the lowest water supply coverage wherein only $56 \%$ of the total population had access to the service in which almost half $(48 \%)$ of the rural community relied on unimproved water sources [6]. The majority of rural residents who obtained access mainly rely on boreholes with hand pumps [8]. The limited capital investment needed to achieve the target, which is about three times the current investment levels [4], dependence on unimproved sources [6], and sustainability of existing infrastructures [9] are the main challenges for the sector.

Several studies evaluating rural water services in developing countries prompt that sustainability and continuous delivery of services are the foremost problems coupled with expanding the access for the unserved. To tackle the problem, governments and donor agencies are spending billions of dollars every year. Despite efforts, many water points failed to continuously provide services throughout the span of time that they were supposed to [10]. According to an assessment made by rural water supply and sanitation networks in selected sub-Saharan African countries in the year 2016, 22.5\% of rural water services were non-functional at visit time [11]. Some other studies claim that the figure of non-functionality reaches 35\% [12], while operational failures stand at $60 \%$ [13]. Reasons cited for non-functionality are universal and multidimensional [14,15], constituting institutional, management, technical, financial, and environmental issues. Fragmented institutional responsibilities, weak local management institutions, and stalled decentralization [16], inefficient service providers [17], inefficient tariff, unreliable quality, and quantity [18] are some of the crucial problems. In many developing countries, sustainability and continuous delivery of the services receive negligible attention compared to the construction of water supply projects [19].

Studies made on the sustainability of rural water services gave prominence to a demandresponsive approach than that of a supply-driven approach, claiming that the former is a relatively better way of sustaining rural water services. The approach was initially designed and accepted by governments in the 1990s following the poor performance of supply-driven approaches in rural water services [20]. It opened a way for participation of beneficiary communities in planning, choice of technology, and source, while giving the role of operation and maintenance management to representative user committees [20]. It is applauded in improving the sense of ownership, increase functionality, and playing a role in improving the sustainability of the services [21,22]. Some studies criticized the demand-driven approach by citing the limitations the communities have in managing the operation and maintenance management of the facilities [23]. The supply-driven approach solely depends on the provision of services by external actors while the demand-driven approach gives room for participation of communities in the development and management of their water supply facilities [24]. Though the demand-driven approach is praised against the supply-driven, many still believe that a better way of ensuring the sustainability of rural water services need to be in place since it is assumed by many that rural water services still suffer from sustainability problems.

Even though attempts were made to assess the role of demand responsive factors, the impact of project implementation management modalities was hardly studied in the area. Additionally, most of the previous studies were relying on a qualitative assessment of sustainability. To the best of our knowledge, Ethiopia became the first country from the sub-Saharan African region to adopt different project implementation management modalities in the water supply, sanitation, and hygiene (WASH) implementation framework which was sanctioned in 2011. This move makes the country a pioneering figure in embracing four alternative project implementation management modalities (i.e., community, local government, self-supply, and other external sources including NGOs and charity organizations) irrespective of its budgetary sources for the purpose of undertaking the construction of new water facilities [25]. 
Thus, this study was designed to empirically assess the implications of project implementation management modalities on the sustainability outcomes of rural water services in Abichu Gna district, Ethiopia. It focused on factors internal to the community affecting sustainability using sustainability assessment indicators. The aim of the study is to (i) assess the sustainability of rural water services, and (ii) assess and test the impact of project implementation management approaches on sustainability outcomes of rural water services. It provides evidence on the sustainability effectiveness of community-managed vis-à-vis other conventional demand-driven project implementation management approaches. The output of the study gives a policy indication in the rural water infrastructure management strategy of attaining optimal sustainability.

\section{Background: Community-Managed Project Approach}

Though there existed controversies in top down and bottom up development approaches, many studies support a bottom-up development approach, especially in rural community development projects. Proponents of a bottom-up development approach believe that the approach gives room for wider participation of communities which is capable of maintaining sustainability $[26,27]$ and criticises the top-down development approach that communities perceive government is responsible for service delivery [28], which weakens communities' sense of ownership. The bottom-up approach is not without criticism in that it suffers a low level of community capacity and knowledge constraints [29]. In principle, rural water policies in many sub-Saharan African countries encourage rural water services to follow a bottom-up development approach by permitting water points to be managed at the lowest decentralized level $[25,30]$ though it is a practical fact to observe role changes in which other bodies of the government and their development partners engage in many rural water infrastructures. The community-managed project approach is among the four project implementation management modalities adopted by the government of Ethiopia and included in the One WASH national program in 2011, which opted to follow a bottom-up approach [25].

Community-managed project is an approach that gives communities the responsibility to plan, implement, and manage both the construction and operation and maintenance of rural water services [31]. The approach passes through the following sequence of steps [32]: (1) promotion: a step in which promotion is made about the project to communities; (2) application: a stage in which communities organize themselves, discuss their water problem, select water sanitation, and hygiene committees (WASHCOs). It is made up of seven people who live in the user community and acts on their behalf with respect to water issues and takes the lead in managing water facilities, and, finally, submit applications to the district water supply, sanitation and hygiene team (DWT), which is the highest government body made up of seven people, which makes decisions related to funds allocated to water resource development and management in the district, for appraisal and approval; (3) appraisal: desk and field appraisal of applications is made by water professionals that submit results to DWT for approval; (4) approval: DWT makes the final decisions on applications; (5) funding agreement: this is a step in which a funding agreement is made between the district administrator on behalf of the DWT and head of the WASHCOs; (6) contracting and procurement: after getting funds, WASHCOs, on behalf of communities and technical support from the district water office, an office mandated for development and management of water resources in the district, make contracts and procurements; (7) construction: this is conducted by hired contractors under the project management role of WASHCOs and technical support from district water office; and (8) post-construction operation and maintenance management by WASHCOs on behalf of communities. The project cycle permits communities to make an informed choice about the level of services, technology type, and reveals their level of participation.

The main distinguishing features of the community-managed project approach that differentiates it from local government- and other external actor-managed project approaches is the flow of fund transfer, project management role, and procurement responsibility [25]. In the community-managed project approach, the budget assigned for construction of water services is directly transferred 
to the community based on approval of DWT through a designated micro-credit and saving association opened by the name of WASHCOs while the allocated money is not directly transferred to the community, but retained in the account of the respective organizations in local and other externally-managed project approaches.

The communities through representative user WASHCOs are responsible for the overall process of their water supply development, including planning, construction management, financial responsibility, implementation, operation and maintenance management of water services in community-managed project approaches. In local government- and other externally-managed project approaches, the role of communities are restricted to planning, participation in the construction process, and operation and maintenance management by leaving the role of construction and financial management to the structures of the governments, NGOs, and/or charity organizations. Materials and services required in the construction of water services are procured by WASHCOs through structured external support in community-managed project approaches, but the structures of the governments are responsible in local government, and NGOs or charity organizations in other externally-managed project approaches.

\section{Materials and Methods}

\subsection{Study Area}

Ethiopia is one of the avenues that offers a viable context to carry out a study on the sustainability of rural water services' performance whose constructions were run by different project implementation management approaches. The country had a population of 105 million in 2017 [33], the second most populous country in Africa next to Nigeria in which $79.7 \%$ of the total population lives in rural areas [34]. It is one of the fastest growing economies in the region with an average annual growth rate of $10.3 \%$ from year 2005/2006 to 2015/2016, compared with a regional average of 5.4\% [35]. According to 2015 UNICEF/JMP estimates, the country ranked among the lowest sub-Saharan African countries in water supply coverage in which only $51 \%$ of the total population had access to clean water [6].

Oromia region, the largest national state in the country in terms of population and area coverage [36] was purposively selected for the study. Among districts found in the region, Abichu Gna was purposively selected based on the availability of the highest possible number of rural water services constructed by project implementation management approaches that are regarded as the core issues the current study is anchored on. The district is found in North Shoa zone of Oromia regional state, about $271 \mathrm{~km}$ from the capital city of the country, Addis Ababa [37]. According to the data we obtained from the district water office, it has 19 peasant associations and one urban part with a total population estimated to be 100,741 . The livelihood of the populations of the area mainly depends on agriculture and the socio-cultural conditions are almost similar. The area is mostly high land ranging from 2590 to 2843 meter above sea level which accounts for about $92.0 \%$ of the total area, and data analyzed from the year 2011/2012 to 2016/2017 shows an average annual rainfall of $950 \mathrm{~mm}$. The rural water supply coverage of the district was $76.2 \%$ in the year 2017. A total of 658 rural water points were constructed and serving the community, among which 312 are hand pumps [38]. The representative of users WASHCOs are in charge of the post construction operation and maintenance management despite the fact that there exists a difference with regard to the construction of water points in the area. The following figure (Figure 1) shows the location of water points under the study. 


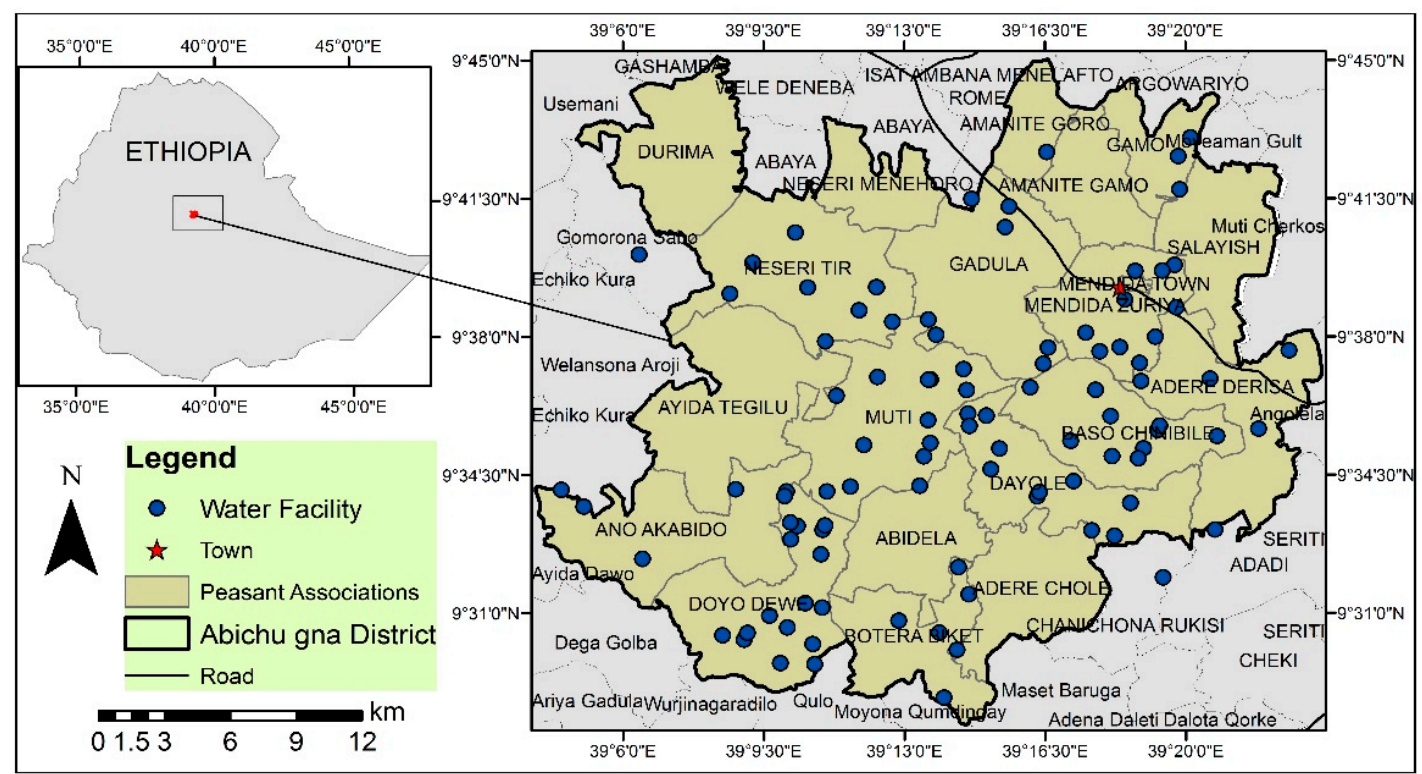

Figure 1. Study site and location of community hand pumps. (Source: authors' work from Google Maps).

\subsection{Data Collection}

Data supporting the study were collected between December 2017 and April 2018 in four separate operations consisting: (a) an interview of 612 rural households benefiting from 102 water services; (b) an interview held with 387 WASHCO members drawn from 102 water services; (c) an observation carried out to gather data on the technical status of 102 water services; and (d) a document analysis conducted on the records kept by 102 WASHCOs. A total of ten trained local enumerators made all operations in the local language, Afan Oromo. They were selected from the water sector based on their years of professional experience, educational background, and knowledge of the local language. The data collection was made with consent and permission of the local communities and the government. The questionnaires were adopted for implementation after a pilot survey was conducted on 15 households and five water services.

The household survey revealed factors such as their perception of WASHCO selection, transparency of WASHCOs, participation in tariff payment, satisfaction with the level of services and their awareness about water shade management plan. A set of data gathered from 606 households was used for analysis, excluding six response bias cases with poor respondent understanding or concerns about the accuracy of responses. An interview aiming at performance appraisal that encompasses institutional, managerial, financial, technical, and environmental matters was held with WASHCOs in charge of managing the selected water services. A similar step was followed while analyzing the records and files kept by them. The water point observation was made by preparing an assessment checklist which captured technical sustainability of the system including functionality, inclusiveness of design which ensure the ease of a potentially marginalized group of the population including aged, women's, and people with disabilities, the sanitary condition of surrounding, drainage condition, and risk of flooding.

Communal hand pumps fitted with Afridev, which is a dominant type of pump in the area, were selected for the study. Though the country adopted four project implementation management approaches, due to the unavailability of the self-supply management approach in the study area as it is rarely practiced in the country, our study focused on the other three management modalities. Accordingly water points are included in the study only if they were constructed by project implementation modalities under the study. We employed a cluster-based random sampling method of data collection to ensure that every household of the community and water services can get an equal chance of being selected. A perfect response rate was registered during the campaign due to the fact 
that the interviewers were experts from the district water office that often meets with the communities which might boost their confidence in answering the questions.

\subsection{Construction and Measurement of Variables}

Due to the multidimensional relations between user communities and the water systems [39], measuring sustainability outcomes of water services in a particular community requires data about user's preference and decision-making behavior related to water, and the operation and maintenance management of the system. Multiple characteristics of sustainability make it tough to quantify, due to the fact that available data on the traits and sustainability indicators vary when examined in light of types of technology and countries [40].

Different authors had made attempts to develop sustainability indicators to measure the sustainability performance of water services. Among them, a multi-criteria approach [41], life cycle thinking approach [15], and the sustainability index tool prepared by United States Aid for International Development (USAID) in collaboration with Rotary International [42] appear to be worth mentioning. Despite the existence of various sustainability measurement indicators in recent years, there is neither scholarly agreement on what methods must be used to measure the outcomes in water services nor possible rationalization in the literature for preferring one criterion to another [43]. In spite of the above mentioned indeterminacy, there is a tacit convention that performance is such a multifaceted concept within which institutional, managerial, financial, technical, and environmental indicators are embedded. Each of these indicators also comes out along with other factors/frames of reference.

The following variables and factors were used in the study since the study is confined to hand pump types of rural water services. They were built on the conceptual framework of sustainability assessment measurement developed by USAID in collaboration with Rotary International and factors contextualized by consultation with water sector professionals according to the country's situation. Due to the relatively large number of factors the study has, exploratory factor analysis is employed and used in the study as the technique is recommended to obtain a small set of variables from a given large set of factors [44]. The Cronbach statistic is typically used as a reference of the consistency and reliability of the combined factors [45], which is used in the study.

Institutional sustainability. Two variables were used to measure institutional sustainability in the analysis. The existence of institutions that were built in accordance with the standards set by the country was one of the variables of the study. This variable encompasses: (1) the existence of WASHCOs; (2) the existence of caretakers, which are selected from beneficiary communities and responsible for preventive maintenance and daily operation of the water facility; and (3) the existence of WASHCOs as per national standard with regard to gender composition (which sets at least $50 \%$ of WASHCO members shall be women). As only one factor emerged in exploratory factor analysis, dichotomous responses to the three factors $(0=$ no, $1=$ yes $)$ were summed as a composite existence of institutions which has been constituted in line with national norms and standards measure (Cronbach's alpha reliability coefficient $=0.73$ ). The second institutional sustainability indicator represented the democratic election of WASHCOs. A dichotomous indicator of community perception $(0=$ no, $1=$ yes $)$ was created based on households response to the question. The percentage of households reporting democratic participation in selecting their WASHCO reflected the aggregate level of democratic involvement of communities in selecting WASHCOs.

Management sustainability. The survey included the following series of questions related to the management performance of WASHCOs and caretakers: (1) is the management roles and responsibilities of WASHCOs clearly defined? (2) Does the WASHCO carry out its technical duties? (3) Does the WASHCO carry out its administrative duties? (4) Does the WASHCO carry out its financial management responsibilities? (5) Does the caretaker carry out its technical responsibilities? (6) Are the WASHCO meetings conducted at minimum frequency stipulated in their law? As only one factor emerged in the exploratory factor analysis, dichotomous responses to the six items $(0=$ no, $1=$ yes $)$ 
were summed as a composite management sustainability performance measure (Cronbach's alpha reliability coefficients $=0.71$ ) .

Financial sustainability. Four variables were used to measure the financial sustainability in the analysis. The first was an indicator of water services tariff setting compliance with the national regulations which include the existence of: (1) water tariff rule; (2) the tariff set in line with national regulations; and (3) social tariff, a special tariff payment system designed for low income and other vulnerable groups. As only one factor emerged in exploratory factor analysis, dichotomous responses to the three factors $(0=$ no, $1=$ yes $)$ were summed as a composite tariff setting compliance with national regulation measure (Cronbach's alpha reliability coefficient $=0.74$ ). The second indicator represented the regularity and sufficiency of tariff collection. WASHCO interviews and document observation were made to assure: (1) the regularity of tariff collection; and (2) the tariff paid can cover the operation and maintenance cost. As only one factor emerged in exploratory factor analysis, dichotomous responses to the two factors $(0=$ no, $1=$ yes $)$ were summed as a composite regularity and sufficiency of tariff collection measure (Cronbach's alpha reliability coefficients $=0.71$ ). The third variable represented the effectiveness of WASHCOs in demonstrating financial management and accounting'. The variable was measured by the interviews conducted with WASHCOs and observation of financial records. Exploratory factor analysis revealed three factors among these variables: (1) the existence of financial records; (2) the existence of bank account; and (3) audit. Dichotomous responses to the three factors $(0=$ no, $1=$ yes $)$ were summed as a composite WASHCO demonstrates effective financial management and accounting measure (Cronbach's alpha reliability coefficients $=0.73$ ). The final variable was the number of households paying tariff. A dichotomous indicator of tariff payment $(0=$ no, $1=$ yes) was created based on households' responses to the question. The percentage of households reporting paying the tariff reflected the aggregate level of households paying tariff.

Technical sustainability. Three variables were used to measure the technical sustainability of water services in the analysis. The first was an indicator of functionality, inclusiveness of design and standard which includes: (1) functionality; (2) standard as per the national regulation; and (3) inclusiveness of design. As only one factor emerged in exploratory factor analysis, dichotomous responses to the three factors $(0=$ no, $1=$ yes $)$ were summed as a composite functionality, inclusiveness of design and standard measure (Cronbach's alpha reliability coefficients $=0.67$ ). The second technical sustainability indicator represented compliance of hand pump with standards and norms in terms of siting and public health risk. Water point observation was made to assess three factors: (1) maintenance of sanitary surrounding; (2) existence of drainage; and (3) existence of flooding control. As only one factor emerged in the exploratory factor analysis, dichotomous responses to the three factors $(0=$ no, $1=$ yes $)$ were summed as a composite compliance of hand pump with standards and norms in terms of siting and public health risk measures (Cronbach's alpha reliability coefficients $=0.69$ ). The third variable represented households' satisfaction with the level of services which includes: (1) quantity (availability throughout the year); and (2) quality. As only one factor emerged in the exploratory factor analysis, dichotomous responses to the two factors $(0=$ no, $1=$ yes $)$ were summed as a composite households satisfaction with the level of services measure (Cronbach's alpha reliability coefficients $=0.72$ ).

Environmental sustainability. Three variables were used to measure environmental sustainability in the analysis. The first was an indicator of the existence of local watershed management plan related to water points. A dichotomous indicator of the availability of a watershed management plan $(0=$ no, $1=$ yes $)$ was created based on results obtained from field observation. The percentage of water services having a watershed management plan reflected the aggregate level of water services having a watershed management plan. The second variable was related to communities' awareness about the watershed management plan related to water services. A dichotomous indicator of community awareness $(0=$ no, $1=$ yes $)$ was created based on households' responses to the question. The percentage of households having awareness reflected the aggregate level of households' awareness about watershed management plan. The third variable was related to environment-related adaptation measures (i.e., afforestation, and cut off drain) incorporated in the development of water supply 
services. A dichotomous indicator of community adaptation measure $(0=$ no, $1=$ yes $)$ was created based on the observations towards committees' responses. The percentage of water services having environment related adaptation measures reflected the aggregate level of water services having environment-related adaptation measures incorporated in the development of water services.

\subsection{Analysis}

The analysis was made to measure sustainability performance and find out the existence of a statistically significant difference among project implementation management modalities. Accordingly, post hoc tests were conducted using one-way ANOVA for numeric and continuous variables and a chi-squared test was employed for dichotomous variables to determine whether the groups of implementation management modalities are statistically significant regarding sustainability performance outcomes. Eventually, differences were identified using Statistical Package for the Social Sciences (SPSS) version 25, of International Business Machine (IBM) Corporation, which is based in Armonk, New York, Unites States.

\section{Results}

\subsection{Sustainability Performance of Water Services}

\subsubsection{Institutional Performance}

A study was conducted to assess factors associated with institutional sustainability performance of water services under the study. To begin with, it could be inferred from Table 1 that all of the water services had WASHCOs expected to manage the operation and maintenance of the system. Additionally, an interview was held with respondents to know if they were involved in electing/selecting WASHCOs. As a result, it was found out that $68.1 \%$ of the respondents believe that their committees were selected democratically with the involvement of the entire beneficiary community. When it comes to the gender composition of the WASHCOs, $51.0 \%$ of the total water services had more than $50 \%$ of women members which is complying with the national standard with regard to gender composition. Less than half of water services $(45.1 \%)$ had caretakers responsible for day-to-day operation and minor maintenance of the system.

We also looked at whether there was a difference between project implementation management modalities in institutional sustainability factors. Accordingly, the democratic election of WASHCOs, the composition of WASHCOs that meets the national standard and existence of caretakers stood highest among water services constructed by the community-managed project approach.

\subsubsection{Management Performance}

In the study area, community representative WASHCOs are expected to manage operation and maintenance of water services with clearly defined roles and responsibilities. In view of that, they were asked to respond to five questions related to their awareness about their roles and responsibilities, how they are discharging their duties, and committee meetings. Table 1 illustrates that only $81.4 \%$ of WASHCOs clearly know their duties and responsibilities out of which $22.6 \%$ did minor maintenance at least once in the project's lifetime. The interview result revealed that $72.6 \%$ and $60.8 \%$ of them were engaged in at least one of the administrative and financial duties, respectively. With regard to committee meetings which is conducted biannually according to national norm, $54.9 \%$ of WASHCOs reported that they were conducting at least once in a minimum standard. When it comes to management performance of caretakers, among caretakers that were found in $45.0 \%$ of water services under the study, $37.2 \%$ of them were at least engaged in preventive maintenance and daily operation of the water facilities. 
Table 1. Sustainability performance of water services under the study by project implementation modality.

\begin{tabular}{|c|c|c|c|c|c|c|c|c|}
\hline \multirow{2}{*}{ Factors } & \multicolumn{2}{|c|}{ Community $(n=34)$} & \multicolumn{2}{|c|}{$\begin{array}{l}\text { Local Government } \\
\qquad(n=34)\end{array}$} & \multicolumn{2}{|c|}{$\begin{array}{l}\text { Other External Actors } \\
\qquad(n=34)\end{array}$} & \multicolumn{2}{|c|}{ Total $(n=102)$} \\
\hline & Mean & SD & Mean & SD & Mean & SD & Mean & SD \\
\hline \multicolumn{9}{|l|}{ Institutional Performance } \\
\hline Water services having caretakers $(\%)$ & 94.12 & 23.88 & 5.88 & 23.90 & 35.29 & 48.51 & 45.10 & 50.24 \\
\hline $\begin{array}{l}\text { Water services in which WASHCOs constituted in line with a national standard regarding } \\
\text { gender }(\%)\end{array}$ & 91.18 & 28.79 & 32.35 & 47.49 & 29.41 & 46.25 & 50.98 & 50.24 \\
\hline $\begin{array}{l}\text { Households who believe that WASHCOs have elected democratically with the } \\
\text { involvement of the entire community }(\%)\end{array}$ & 81.86 & 38.60 & 56.86 & 49.60 & 65.67 & 47.60 & 68.14 & 46.60 \\
\hline \multicolumn{9}{|l|}{ Management Performance } \\
\hline Water services in which roles and responsibilities of WASHCOs are clearly defined (\%) & 100.00 & 0.00 & 82.35 & 38.70 & 61.76 & 49.34 & 81.37 & 39.12 \\
\hline Water services in which WASHCOs are carrying out their technical responsibilities (\%) & 35.29 & 48.51 & 5.88 & 23.88 & 26.47 & 44.78 & 22.55 & 42.00 \\
\hline Water services in which WASHCOs are carrying out their administrative duties (\%) & 91.18 & 28.79 & 61.76 & 49.33 & 64.71 & 48.51 & 72.55 & 44.84 \\
\hline $\begin{array}{l}\text { Water services in which WASHCOs are carrying out their financial management } \\
\text { responsibilities }(\%)\end{array}$ & 91.18 & 28.79 & 38.24 & 49.33 & 52.94 & 50.66 & 60.78 & 49.06 \\
\hline Water services in which caretakers are carrying out their duties (\%) & 82.35 & 38.70 & 2.94 & 17.15 & 26.47 & 44.78 & 37.25 & 48.59 \\
\hline \multicolumn{9}{|l|}{ Financial performance } \\
\hline Water services tariff has been set $(\%)$ & 94.12 & 23.88 & 76.47 & 43.06 & 88.24 & 32.70 & 86.27 & 34.58 \\
\hline Water services tariff has been set as per national standard (\%) & 85.29 & 35.94 & 70.59 & 46.25 & 85.29 & 35.94 & 80.39 & 39.90 \\
\hline $\begin{array}{l}\text { Water services in which tariff has been set by considering poorest in the community } \\
\text { through social tariff (\%) }\end{array}$ & 55.88 & 50.40 & 32.35 & 47.49 & 44.12 & 50.40 & 44.12 & 49.90 \\
\hline Water services in which tariff is regularly collected (\%) & 85.29 & 35.95 & 32.35 & 47.49 & 52.94 & 50.66 & 56.86 & 49.71 \\
\hline Water services in which tariff has covered or exceeds operation and maintenance cost $(\%)$ & 55.88 & 50.40 & 11.76 & 32.70 & 17.65 & 38.70 & 28.43 & 45.33 \\
\hline Water services in which WASHCOs keeping financial ledger $(\%)$ & 70.59 & 46.25 & 23.53 & 43.06 & 41.48 & 49.96 & 45.10 & 50.00 \\
\hline Water services which opened bank account for operation and maintenance $(\%)$ & 70.59 & 46.25 & 14.71 & 35.95 & 47.06 & 50.66 & 44.12 & 49.90 \\
\hline Water services in which at least their finances are audited internally $(\%)$ & 38.24 & 49.32 & 0.00 & 0.00 & 14.71 & 35.95 & 17.65 & 38.31 \\
\hline Households paying tariff $(\%)$ & 73.56 & 44.20 & 31.87 & 46.70 & 41.67 & 49.40 & 49.02 & 50.00 \\
\hline Households who believe that the WASHCOs are transparent in finance (\%) & 52.45 & 50.10 & 22.06 & 41.60 & 20.01 & 40.20 & 31.54 & 46.50 \\
\hline
\end{tabular}


Table 1. Cont.

\begin{tabular}{|c|c|c|c|c|c|c|c|c|}
\hline \multirow{2}{*}{ Factors } & \multicolumn{2}{|c|}{ Community $(n=34)$} & \multicolumn{2}{|c|}{$\begin{array}{l}\text { Local Government } \\
\quad(n=34)\end{array}$} & \multicolumn{2}{|c|}{$\begin{array}{l}\text { Other External Actors } \\
\qquad(n=34)\end{array}$} & \multicolumn{2}{|c|}{ Total $(n=102)$} \\
\hline & Mean & SD & Mean & SD & Mean & SD & Mean & SD \\
\hline \multicolumn{9}{|l|}{ Technical Performance } \\
\hline $\begin{array}{l}\text { Water services which is designed, constructed and maintained to ensure the ease of by a } \\
\text { potentially marginalized group of population }(\%)\end{array}$ & 41.18 & 49.96 & 26.47 & 44.78 & 20.59 & 41.04 & 29.41 & 45.79 \\
\hline Water services complies with national norms about sitting (\%) & 94.12 & 23.88 & 97.06 & 17.15 & 76.47 & 43.06 & 89.22 & 31.17 \\
\hline Water services sanitary surrounding meets with local standard (\%) & 82.35 & 38.69 & 67.65 & 47.49 & 50.00 & 50.70 & 66.67 & 47.37 \\
\hline $\begin{array}{l}\text { Water services drainage is controlled to minimize standing water and water vector } \\
\text { diseases }(\%)\end{array}$ & 91.18 & 28.79 & 70.59 & 46.25 & 73.53 & 44.78 & 78.43 & 41.33 \\
\hline Water services the location of the borehole is not at the risk of flooding & 79.41 & 41.04 & 61.76 & 49.33 & 58.82 & 49.96 & 66.67 & 47.34 \\
\hline Households satisfied with quantity (\%) & 73.00 & .447 & 48.00 & .501 & 42.00 & .494 & 54.00 & 49.90 \\
\hline Households satisfied with quantity (\%) & 70.00 & .459 & 49.00 & .501 & 38.00 & .486 & 52.00 & 50.00 \\
\hline \multicolumn{9}{|l|}{ Environmental Performance } \\
\hline Water services having local water shade management plan related to their water point (\%) & 35.29 & 48.51 & 41.18 & 49.96 & 44.12 & 50.40 & 40.20 & 49.27 \\
\hline Households having awareness about water shade management plan (\%) & 28.92 & 45.50 & 22.55 & 41.90 & 22.06 & 41.60 & 25.00 & 43.00 \\
\hline
\end{tabular}


A result obtained from a comparative analysis conducted on project implementation management approaches reveals that in most factors, local government was performing lowest as compared to other external actors and community-managed projects. Knowledge of roles and responsibilities, achieving technical, administrative, and financial duties, making frequent committee meeting, and achieving caretaker duties were found to be better in community-managed projects.

\subsubsection{Financial Performance}

The operation and maintenance cost of water services in the study area shall be covered by user communities through tariffs. Accordingly, observations and interviews were made with WASHCOs and households to discover the financial performance of water services (Table 1). The result revealed that $86.3 \%$ of water services fix the tariff amount by meetings convened with beneficiary communities. When determining the water tariff, $44.1 \%$ of them decided that the tariff they made gives a provision for the most impoverished members of the community. From the total water services, only $56.9 \%$ of them were collecting revenues as per the agreement reached in meetings, though the timing of tariff collection differs.

Out of the total households interviewed, only $49.2 \%$ were paying the water tariff that had been used for operation and maintenance purposes. As per the calculation made, the tariff paid could cover the operation and maintenance cost of only $28.4 \%$ of water services, and the revenue of more than $71 \%$ of water services was not sufficient to cover the cost, which poses risk of financing. Major deviations were observed between groups under the study in which $72.6 \%, 42.6 \%$, and $24.4 \%$ of households were paying the tariff pertinent to the local laws of the communities for water services constructed under the community-, other external actors-, and local government-managed project implementation modalities, respectively. The tariff paid by households were able to cover the operation and maintenance cost of $43.9 \%, 13.0 \%$, and $9.0 \%$ of water points, respectively.

WASHCOs are responsible for the overall financial management of water services. The observation result revealed that from 102 water services under the study, $45.1 \%$ of water service WASHCOs kept a financial ledger, while $44.1 \%$ of water services opened a bank account at Oromia Credit and Saving Share Company (OCSSCO), a micro bank mandated to give financial services for rural communities in the study area. Financial transparency of WASHCOs plays a pivotal role in tariff collection efficiency and maintaining the financial sustainability of rural water services. The finances of $17.7 \%$ of water services were internally audited by committee auditors. The interview result obtained from $57.2 \%$ of the households revealed that revenues and expenses were not made available to them during the projects' lifetime. The obtained result indicates that projects constructed by the community-managed project approach were performing highest in terms of financial management leaving behind as competitors other external actor- and local government-managed project approaches, respectively.

\subsubsection{Technical Performance}

The technical performance of the study involved five factors related to functionality and continuous delivery of the system which includes functionality, households' satisfaction with the level of quality and quantity, inclusiveness of design, and standard. The remaining factors were related to hand pump compliance with norms and standards of water services regarding siting and public health.

As a result, from the total water services observed during the study, $92.2 \%$ of them were functional at visit time (Table 1). Households were invited to rate how satisfied they are with the quantity and quality of water supply they receive from the water points. Accordingly, it was determined that only $54.0 \%$ of the respondents are satisfied with the quantity, while $52.0 \%$ of the partakers replied that they are satisfied with the quality. The comparison made between project implementation management approaches revealed that water services constructed by the community-managed project approach was found to be more functional, and more satisfactory for the households than other external actors and local government managed project approaches. 
The technical observation was made to pledge that the water points are designed, constructed and maintained to ensure the ease by marginalized sections of the society. Accordingly (Table 1), 29.4\% of water services have met the criteria, and there existed a difference among project implementation modalities. A similar observation conducted on the surrounding water services revealed that $89.2 \%$, $66.7 \%, 78.4 \%$, and $66.4 \%$ of water services were constructed in compliance with the locally set standard, surrounding sanitary maintained, possessing good drainage system, and minimizing risks of flooding, respectively. A comparison of results among project implementation management approaches reveals the local government-managed project approach performed higher in compliance with national norms about siting factors, while the community-managed project performed better in the rest of the three factors.

\subsubsection{Environmental Performance}

In order to maintain the long-term functionality and continuous delivery of services, environmental factors affecting water points needs to be maintained with the participation of communities. The environmental sustainability of rural water services under the study revealed that a great deal of work still needs to be done to minimize the effect of environmental impacts on water services. As shown in Table 1, 40.2\% of water services under the study had a local water shade management plan related to their respective water services. Among households that took part in the interview, only $25.0 \%$ of households had awareness about water shade management of their water services. Despite the existence of watershed management plans and some level of awareness among the communities, only $16.7 \%$ of water services were identified risks and measures are being taken to rectify the identified problems. In most of the environmental sustainability factors, except awareness, all project implementation management approaches were performing on the same level.

\subsection{Project Implementation Management Modalities and Sustainability Outcomes}

The analysis was made to assess the existence of a statistically significant difference among project implementation management modalities in sustainability outcome variables (Table 2).

Institutional sustainability: The existence of institutions which have been constituted in line with national norms and standards differed across project implementation management modalities under the study (Table 2). Interviews conducted with WASHCOs revealed it was found to be the highest among water supply services construction managed by communities, which differed significantly from local government and other external actors. Though projects managed by other external actors registered higher institutional performance than local government, a significant difference was not observed between them. The perception of households about the democratic selection of WASHCO members was also highly related to project implementation management modalities. Survey data from the household interview indicates it was lowest in local government- and significantly highest in community-managed project approaches.

Management sustainability: The observation and interview results on the management performance of WASHCOs show that there existed a significant and high difference between community and other project implementation management approaches (Table 2). The management performance was lowest in the local government-managed approach, but a significant difference was not found with other external actor-managed project approach. 
Table 2. Comparisons of project implementation management modalities on major sustainability variables in the analysis a

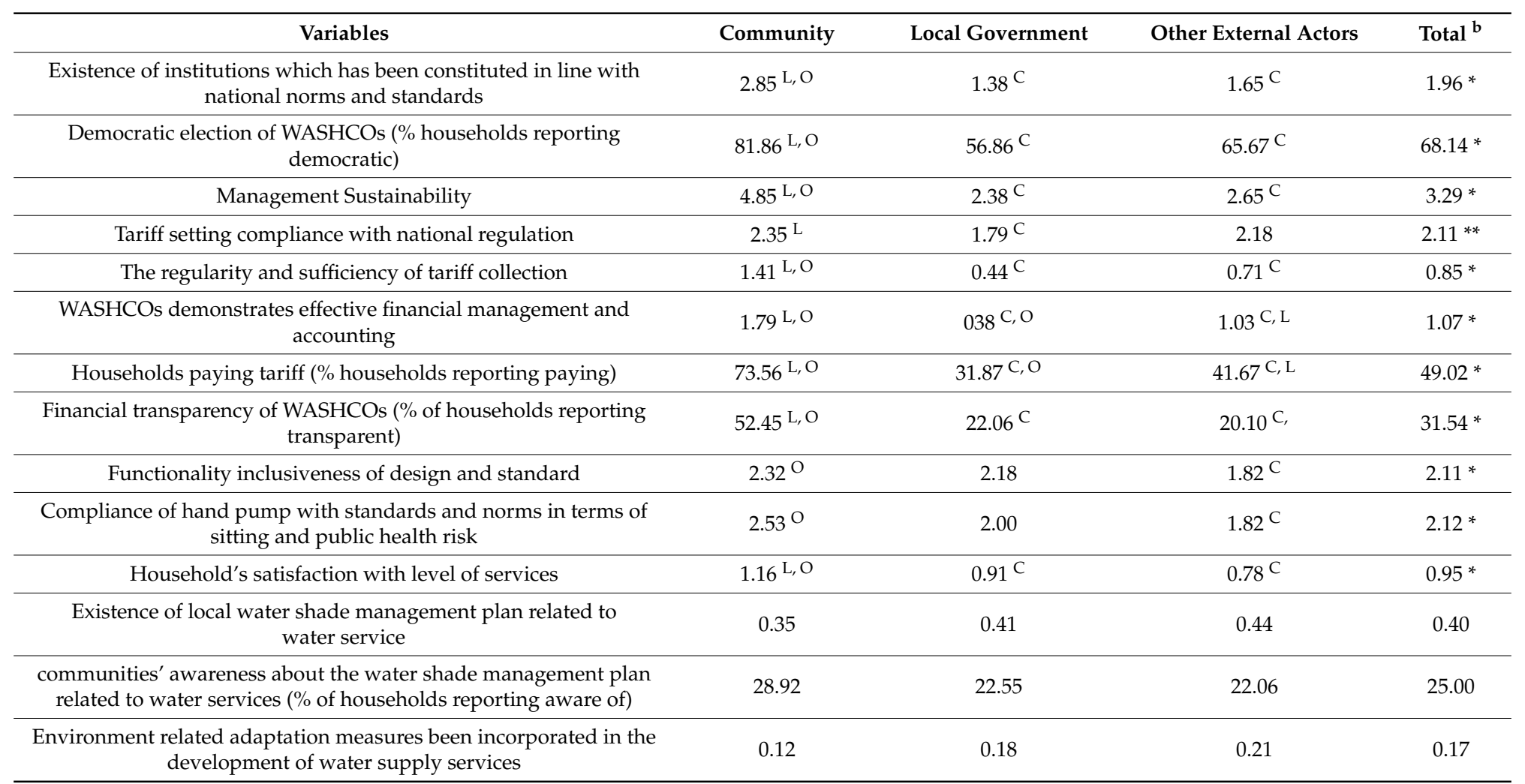

a Given as mean values of variables except democratic election of WASHCOs, households paying tariff, financial transparency of WASHCOs, and community awareness about the water shade management plan related to water services. Superscript codes indicate a statistically significant difference between the two project implementation management approaches as per the results of post hoc and chi-squared tests. Codes for project implementation management approaches: $\mathrm{C}=\mathrm{Community,} \mathrm{L}=$ Local Government, $\mathrm{O}=\mathrm{Other}$ External Actors. ${ }^{\mathrm{b}}$ Asterisks indicate the statistical significance of differences among project implementation management modalities at significance levels of ${ }^{*} p<0.01$, ${ }^{* *} p<0.10$. 
Financial sustainability: Compliance of tariff setting with national regulations was highest in the community-managed project approach, while external actors rank next, and local government last, though there was no statistically significant difference among them. The regularity and sufficiency of tariff collection found a mirror reflection of compliance of tariff setting with national regulations. It was highest in community-managed project approach and average in other external actors, and lowest in the local government management project approach. However, the other external actor-managed project approach no longer differed significantly from local government. The effectiveness of WASHCOs in handling financial management and document related tasks is also highly varied among project implementation management approaches (Table 2). The community-managed project approach was highest followed by other external actors and local government. A significant difference was observed among project implementation management approaches. Household survey results on tariff payment show that community-managed projects had a higher and significantly greater number of households paying the tariff than local government- and other external-managed project approaches.

Technical sustainability: The other external actor-managed project approach was the lowest in the two variables of functionality, inclusiveness of standard of water services as well as compliance of water services with standards and norms in terms of siting and public health, which differed significantly from the community-managed project approach. The community-managed project approach performed better than local government in both variables; however, a significant difference was not found. Beneficiary households of water services constructed by the community-managed project approach reported that they are highly satisfied as opposed to the beneficiaries of water services constructed by the local government- and other externally-managed project approaches with a statistically significant result. Other externally-managed projects had the lowest level of satisfaction though they did not significantly differ from local government.

Environmental sustainability: The observation made on the existence of water shade management plan and incorporation of environment-related adaptation measure of water services under the study (Table 2) shows that it was highest in the other external actor-managed project approach followed by local government, and lowest in community-managed project approach. Though there was a difference among project implementation management modalities in both variables, a statistically significant difference was not found among them. The degree to which respondents know about the existence of the watershed management plan of their respective water service was almost the same for local government and other external managed project approaches. Awareness about the water shade management plan of their respective water services was highest in community-managed project approaches and the chi-square test result showed an insignificant difference among project implementation management modalities.

\section{Discussion}

The study offers the following major insights about the sustainability of rural water services and how project implementation management modalities, conveyed by the responsible body for managing the construction of projects, can influence the sustainability of rural water services.

Accordingly, the study revealed that sustainability outcomes of water services were affected by project implementation management modalities under the study. A high level of institutional performance was generated by the community-managed project approach, relatively. This is in harmony with the hypothesis that empowering communities with the project construction management role initiates them to create a relatively stronger institution that involves women responsible for managing the operation and maintenance of the system. The skill and knowledge acquired from managing the construction of the projects and the existence of stronger institutions are associated with management sustainability performance. Relative management sustainability inefficiency was observed in the local government- and other external actor-managed projects. This inefficiency is mainly linked to lack of experience. In the aforementioned project management approaches, the communities were entitled to take over the management role only after projects are completed, and 
handover made to the beneficiaries. Although there is a lack of prior study related to community empowerment in the construction stage, there is evidence that participation is positively affecting sustainability [46,47]. The study found that empowering communities leads to better water service as measured by institutional and management sustainability indicators, implying that the communities are more engaged and committed to sustaining their water services.

A comparable study undertaken on the financial sustainability in sub-Saharan African countries [48] indicated that, on average, $30 \%$ of beneficiary households were paying the tariff, though there exists significant difference among countries. The regularity of the tariff collection and its capacity in covering the operation and maintenance cost was even lower than the figure. On contrary, this study revealed that almost $73.6 \%$ of households were paying the tariff, and a significant proportion was paying on a regular basis for water services construction managed by the communities. There exists a significant difference in financial sustainability performance among the project implementation modalities. The regularity of the tariff collection and percentage of households paying the tariff was also a mirror reflection of the cost of covering operation and maintenance. A significant relationship is observed between the financial transparency and project implementation management approach in which the level of involvement of the communities in selecting the WASHCOs and managing the construction is related to financial transparency. Thus, the study found that to realize a cost recovery system, the involvement of the user communities in managing the construction of their water points can make households pay regularly and sufficiently, and enables WASHCOs to handle proper financial management, which is key in maintaining the financial sustainability of water services.

The technical assessment of the study revealed that $92.2 \%$ of the rural water services under scrutiny were functional at visit time and there existed differences among the project implementation management modalities. The result showed that the community-managed project approach registered a lower non-functionality rate and this result is in contradiction with similar studies made in sub-Saharan African countries which figures a non-functionality rate up to 35\% [11]. The level of satisfaction with regard to the service level, the participation of the communities in keeping sanitation of the surrounding area, and control flooding are also related to the level of empowerment. It is observed that communities do not have the capacity necessary to manage water services in tandem with the required technical skills, standards, and designs. From the results, the technical sustainability of the study came to conclude that if communities are empowered and given a proper managerial role in the construction of water facilities, they can become more capable of shouldering responsibilities in maintaining the functional and technical status of water services. Water shade management plans and environmental adaptation measures taken to maintain the environmental flow of the water services also revealed there is a low level of awareness among the communities on the issues. There is a need to maintain the minimum environmental flow in fulfilling the demand of all water needs $[49,50]$. The low level of environmental protection activities in the study area might have a long-term effect on the availability of water and even in meeting the needs of growing demand due to population pressure.

Generally, the study has provided vital insights that water service projects, where the community is empowered and maintained leadership responsibility in constructing their rural water projects, the outcome was found more sustainable than that of managed by local government, NGOs and charity organizations. A demand-responsive approach gives communities the opportunity to participate rather than a managerial role. In accordance with this, the current study found that the highly-praised conventional demand-driven approach of rural water supply can benefit more in terms of sustainability and continuous delivery of the services if it brings communities to managerial and decision-making positions in the process of constructing water projects. The result is in contradiction with previous research made by Ellie which raised the risk of community management [23]. These might be a clear indication that, as far as sustainability is concerned, the role of governments, NGOs, and charity organizations in construction management of rural water projects might be restricted and areas of particular intervention need to be identified. The facilitative role of involvement taken by the governments, NGOs, and charity organizations in structured support and capacity building 
initiatives to the communities throughout the project cycle might optimize the benefits of sustainable, and continuous, delivery of systems.

\section{Conclusions}

In addition to serving the unserved, sustainability of rural water services is one of the overriding problems for the water sector in developing countries. Different attempts were made to identify factors affecting sustainability in spite of the fact that there is lack of studies on the impact of project implementation management modalities on sustainability outcomes of rural water services. The study has made an attempt to shed light on the relationship between project implementation management modalities and sustainability outcomes of rural water services in Abichu Gna district, Ethiopia. Three different types of project implementation management modalities: community, local government, and other external actors were identified in the area. The USAID sustainability assessment tool was adopted, contextualized, and employed to quantify factors affecting sustainability. The analysis of the data from the study area reveals that the sustainability of rural water services is still a major concern for the sector and different aspects of sustainability of rural water services are significantly affected by project implementation management modalities. The followings are key findings of the study:

Though the community-managed project approach to construction of water projects are not common in sub-Saharan African countries, the evidence from Abichu Gna district reveals that community management of water infrastructures generates higher institutional, managerial, financial, and technical sustainability performance compared to projects managed by local government, NGOs, and charity organizations. In most of the sustainability assessment variables, community-managed projects registered a higher statistically significant difference. We think these results linking the community-managed project approach in greater sustainability of water services can be explained by the reaction of communities to empowerment which increases their awareness and sense of ownership. The experience they are getting from construction management of water points might also give them the necessary skills and knowledge on how to sustain their water services. Thus, in order to attain the sustainable development goal target of the water sector, which aimed at increasing the water supply coverage and improve the functionality of existing water infrastructures, the policymakers and governments of developing countries should work more, besides participation, on the empowerment of user communities in the construction of water points.

The study is limited to low-cost rural water technology of hand pumps and internal factors to the community affecting sustainability. A sort of action research that anchors its analysis on a mix of variables treating external factors and the possibility of engaging the community in the tasks related to other types of rural water construction and its cost implication needs to be conducted.

Author Contributions: Conceptualization: F.M.S. and S.Y.; methodology: F.M.S. and S.Y.; software: F.M.S. and S.Y.; validation: F.M.S. and S.Y.; formal analysis: F.M.S. and S.Y.; data curation: F.M.S. and S.Y.; writing-original draft preparation: F.M.S. and S.Y.; writing — review and editing: F.M.S. and S.Y.

Funding: This work was supported by National Natural Science Foundation of China (No. 71673081).

Acknowledgments: We would like to acknowledge financial support from the Ministry of Commerce and Commercial Services, P. R, of China for financial support during the study time and logistical support from Oromia Regional Water, Mines, and Energy Bureau. We thank study partners from the Ethiopian Ministry of Water, Irrigation, and Energy, regional experts, and district water office experts for their time and commitment during the study period. We are also grateful for all the user households, and water, sanitation, and hygiene committee member, who took their time to respond to our interviews.

Conflicts of Interest: The authors declare no conflict of interest. 


\section{References}

1. United Nations Department of Public Information. Sustainable Development Goals in sync with Africa's Priorities. Available online: https:/ / www.un.org/africarenewal/magazine/december-2015/sustainabledevelopment-goals-are-sync-africa \%E2\%80\%99s-priorities (accessed on 12 November 2018).

2. United Nations. Transforming our World. The 2030 Agenda for Sustainable Development. Available online: https:/ / sustainabledevelopment.un.org/post2015/transformingourworld (accessed on 18 November 2018).

3. United Nations Environmental Program. Financing Sustainable Development: Moving from Momentum to Transformation in a Time of Turmoil. Available online: https://www.un.org/pga/71/event-latest/high-le vel-sdg-financing-lab/ (accessed on 9 November 2018).

4. Hutton, G. Global Costs and Benefits of Drinking-Water Supply and Sanitation Interventions to Reach the MDG Target and Universal Coverage; WHO/HSE/WSH/12.01; World Health Organization: Geneva, Switzerland, 2012.

5. Bhaduri, A.; Bogardi, J.; Siddiqi, A.; Voigt, H.; Vörösmarty, C.; Pahl-Wostl, C.; Bunn, S.E.; Shrivastava, P.; Lawford, R.; Foster, S.; et al. Achieving Sustainable Development Goals from a Water Perspective. Front. Environ. Sci. 2016, 4, 1-13. [CrossRef]

6. United Nations Children's Education Fund (UNICEF); World Health Organization (WHO). Progress on Sanitation and Drinking Water 2015 Update and MDG Assessment. Available online: https: / www.unicef.o rg/publications/index_82419.html (accessed on 12 June 2018).

7. World Bank. Overview Water. Available online: http://www.worldbank.org/en/topic/water/overview (accessed on 2 September 2018).

8. Sansom, K.; Koestler, L. African Handpump Market Mapping Study. Available online: https://wedc -knowledge.lboro.ac.uk/resources/pubs/Handpump_market_study_summary_report.pdf (accessed on 15 February 2018).

9. Ibrahim, S.H. Sustainability Assessment and Identification of Determinants in Community-Based Water Supply Projects using Partial Least Squares Path Model. J. Sustain. Dev. Energy Water Environ. Syst. 2017, 5, 345-358. [CrossRef]

10. Lockwood, H.; Bakalian, A.; Wakeman, W. Assessing Sustainability in Rural Water Supply: The role of Follow-up Support to Communities: Literature Review and Desk Review of Rural Water Supply and Sanitation Project Documents. Available online: https:/ / docplayer.net/35861896-Assessing-sustainabilityin-rural-water-supply-the-role-of-follow-up-support-to-communities.html (accessed on 19 August 2018).

11. Banks, B.; Furey, S. What's Working, Where, and for How Long: A 2016 Water Point Update. In Proceedings of the 7th Rural Water Supply and Sanitation (RWSS) Forum, Abidjan, Côte d'Ivoire, 29 November-2 December 2016. [CrossRef]

12. Baumann, E.; Ball, P.; Beyene, A. Rationalization of Drilling Operations in Tanzania: Review of the Borehole Drilling Sector in Tanzania. 2005. Available online: https://www.sswm.info/sites/default/files/reference _attachments/BAUMANN\%20et\%20al\%202005\%20Rationalization\%20of\%20Drilling\%20Operations\%20i n\%20Tanzania.pdf (accessed on 7 May 2018 ).

13. Sutton, S. The Sub-Saharan Potential for Household Level Water Supply Improvement, Maximizing the Benefits from Water and Environmental Sanitation. In Proceedings of the 31st WEDC Conference, Kampala, Uganda, 31 October-4 November 2005.

14. Smith, G. Rural Water System Sustainability: A Case of Community-Managed Water Systems in Saramaka Communities. Master's Thesis, University of Michigan, East Lansing, MI, USA, 2011.

15. McConville, J.R.; Mihelcic, J.R. Adapting Life-Cycle Thinking Tools to Evaluate Project Sustainability in International Water and Sanitation Development Work. Environ. Eng. Sci. 2007, 24. [CrossRef]

16. The World Bank; UNICEF. Water and Sanitation for All. How The Financing Gap Be Filled: A Discussion Paper; Paper Submitted to World Bank and UNICEF to Support the Sanitation and Water for All Finance Minister Meeting Preparatory Process; The World Bank: Washington, DC, USA, 2017.

17. Whaley, L.; Cleaver, F. Can 'Functionality' Save the Community Management Model of Rural Water Supply? Water Resour. Rural Develop. 2017, 9, 56-66. [CrossRef]

18. Beshah, M.B.; Jarmo, J.H.; Tapio, S.K. Service Failures of Rural Water Supply Systems in Ethiopia and Their Policy Implications. Public Works Manag. Policy 2017, 22, 179-196. [CrossRef] 
19. Bain, R.; Cronk, R.; Hossain, R.; Bonjour, S.; Onda, K.; Wright, J.; Yang, H.; Slaymaker, T.; Hunter, P.; Pruss-Ustun, A.; et al. Global Assessment of Exposure to Faecal Contamination through Drinking Water Based on a Systematic Review. Trop. Med. Int. Health 2014, 19, 917-927. [CrossRef] [PubMed]

20. Whittington, D.; Davis, J.; McClelland, E. Implementing a Demand-Driven Approach to Community Water Supply Planning: A Case Study of Lugazi, Uganda. Water Int. 1998, 23, 134-145. [CrossRef]

21. Marks, S.J.; Davis, J. Does User Participation Lead to Sense of Ownership for Rural Water Systems? Evidence from Kenya. World Dev. 2012, 40, 1569-1576. [CrossRef]

22. Ghazala, M.; Vijayendra, R. World Bank. Community Driven Development. Available online: Siteresources. worldbank.org/INTECAREGTOPCOMDRIDEV / Resources / DECstudy.pdf (accessed on 2 May 2018).

23. Ellie, C. Is Community Management an Efficient and Effective Model of Public Service Delivery? Lessons From the Rural Water Supply Sector in Malawi. Public Admin. Dev. 2015, 35, 263-276. [CrossRef]

24. Whittington, D.; Thorsten, R.; Prokopy, L.; Bakalian, A.; Komives, K.; Wakeman, W. How Well is the Demand-driven, Community Management Model for Rural Water Supply Systems Doing? Evidence from Bolivia, Peru and Ghana. Water Policy 2009, 11, 696-718. [CrossRef]

25. Federal Democratic Republic of Ethiopia. The WaSH Implementation Framework. Available online: https: / / cmpethiopia.files.wordpress.com/2011/11/full-wif.pdf (accessed on 15 April 2018).

26. Chambers, R. Participatory rural appraisal PRA: Analysis of experience. World Dev. 1994, 22, $1253-1268$. [CrossRef]

27. Pound, B.; Snapp, S.; McDougall, C.; Braun, A. Managing Natural Resources for Sustainable Livelihoods: Uniting Science and Participation; Earthscan: London, UK, 2003.

28. Yakubov, M.; Hassan, M. Mainstreaming Rural Poor in Water Resources Management: Preliminary Lessons of A Bottom-Up WUA Development Approach In Central Asia. Irrig. Drain. 2007, 56, 261-276. [CrossRef]

29. Smith, J.L. A Critical Appreciation of the "bottom-up" Approach to Sustainable Water Management: Embracing Complexity rather than Desirability. Local Environ. 2008, 13. [CrossRef]

30. Ministry of Water Resources. Ethiopian Water Resources Management Policy; Ministry of Water Resources: Addis Ababa, Ethiopia, 1998.

31. Community Led Accelerated Water Supply, Sanitation and Hygiene Project. About CMP. Available online: https:/ / www.cmpethiopia.org/page/1011 (accessed on 12 September 2018).

32. Community Led Accelerated Water supply, Sanitation and Hygiene Project. CMP Approach. Available online: https: / www.cmpethiopia.org/page/258 (accessed on 5 September 2018).

33. United Nations Department of Economic and Social Affairs, P.D. World Population Prospects: The 2017 Revision, Key Findings and Advance Tables. Available online: https://population.un.org/wpp/Publicatio ns/ (accessed on 24 September 2018).

34. World Bank Data Base. Rural Population (\% of Total Population). Available online: https:/ / data.worldbank .org/indicator/SP.RUR.TOTL.ZS?locations=ET (accessed on 12 June 2018).

35. World Bank. Ethiopia Economic Update: The Inescapable Manufacturing Service Nexus Exploring the Potential. Available online: https://openknowledge.worldbank.org/handle/10986/29919 (accessed on 18 June 2018).

36. Oromia Regional Bureau of Finance and Economic Cooperation. Oromia National Regional State in Brief. Available online: www.oromiabofed.gov.et/images/stories/rstatistics/Oromia_In_Brief\%20Part_V.pdf (accessed on 12 September 2017).

37. Oromia Regional Bureau of Finance and Economic Development. Socio-Economic Profile of Abichu Gna District. Available online: http:/ / www.oromiabofed.gov.et/index.php?option=com_content\&view=categ ory\&layout=blog\&id=45\&Itemid=62 (accessed on 12 September 2017).

38. Abichu Gna Distrcit Water, Mines and Energy Office. 2017/18 Annual Report; NDP: Mendida, Ethiopia, 2018.

39. Jones, S.A.; Bernhardt, K.; Sanford, L.; Kennedy, M.; Lantz, K.; Holden, T. Collecting Critical Data to Assess the Sustainability of Rural Infrastructure in Low-Income Countries. Sustainability 2013, 5, 4870-4888. [CrossRef]

40. Haysom, A. A Study of the Factors Affecting Sustainability of Rural Water Supplies in Tanzania. Master's Thesis, Cranfield University, Bedford, UK, 2006.

41. Panthie, K.; Bhattarai, S. Framework to Assess Sustainability of Community Based Water Projects Using Multi Criteria Analysis. Ph.D. Thesis, Florida International Universiy, Miami, FL, USA, 2008. 
42. United States Agency for International Aid (USAID) in Collaboration with Rotary International. WASH Sustainability Index Tool. Available online: http://washplus.org/rotary-usaid.html (accessed on 26 October 2017).

43. Madrigal, R.; Alpízar, F.; Schlüter, A. Determinants of Performance of Community-Based Drinking Water Organizations. World Dev. 2011, 39, 1663-1675. [CrossRef]

44. Torres-Reyna, O. Getting Started in Factor Analysis (Using Stata 10): Data and Statistical Services. Available online: https:/ / www.princeton.edu/ \{\}otorres /Factor.pdf (accessed on 25 December 2018).

45. Reynaldo, J.; Santos, A. Cronbach's Alpha: A Tool for Assessing the Reliability of Scales. J. Ext. 1999, 37, 1-4.

46. Peter, G.; Nkambule, S.E. Factors Affecting Sustainability of Rural Water Schemes in Swaziland. Phys. Chem. Earth 2012, 50, 196-204. [CrossRef]

47. Marks, S.J.; Komives, K.; Davis, J. Community Participation and Water Supply Sustainability: Evidence from Hand pump Projects in Rural Ghana. J. Plan. Educ. Res. 2014, 34, 276-286. [CrossRef]

48. Foster, T. Why Financial Sustainability Matters: Evidence from sub-Saharan Africa. In Proceedings of the World Water Week, Stockholm, Sweden, 25 August 2015.

49. Operacz, A.; Wałega, A.; Cupak, A.; Tomaszewska, B. The comparison of environmental flow assessment-The barrier for investment in Poland or river protection? J. Clean. Prod. 2018, 193, 575-592. [CrossRef]

50. Pusłowska-Tyszewska, D.; Tyszewski, S. Attempt at Implementing the 2015 “Ecological Flow Assessment Method for Poland" In the Wieprza River Catchment. Acta Sci. Pol. Form. Circumiectus 2018, 17, 181-193. [CrossRef]

(C) 2019 by the authors. Licensee MDPI, Basel, Switzerland. This article is an open access article distributed under the terms and conditions of the Creative Commons Attribution (CC BY) license (http://creativecommons.org/licenses/by/4.0/). 